\title{
A Case of Middle Turbinate Headache Syndrome Caused by Middle Turbinate Concha Bullosa Included Fungal Ball
}

\author{
Gi Yun Nam, Gwan Choi, Joo Yeon Kim, and Jae Hwan Kwon \\ Department of Otolaryngology-Head and Neck Surgery, Kosin University College of Medicine, Busan, Korea
}

\section{진균구를 함유한 기포성 중비갑개와 연관된 중비갑개 두통 증후군 1 예}

남기윤·최 관 · 김주연 · 권재환

고신대학교 의과대학 이비인후과학교실

\author{
Received November 9, 2013 \\ Revised February 11, 2014 \\ Accepted February 11, 2014 \\ Address for correspondence \\ Jae Hwan Kwon, MD, PhD \\ Department of Otolaryngology- \\ Head and Neck Surgery, \\ Kosin University \\ College of Medicine, \\ 262 Gamcheon-ro, Seo-gu, \\ Busan 602-702, Korea \\ Tel $+82-51-990-6247$ \\ Fax $+82-51-245-8539$ \\ E-mail entkwon@hanmail.net
}

Middle turbinate headache syndrome was the first reported by Wolff and the incidence is rare. It is caused by pneumatization or hypertrophy of the middle turbinate contacts between the nasal septum and the lateral nasal wall, resulting in headache in the periorbital region. The diagnosis is made by anterior rhinoscopy, computerized tomography, and confirmation by the lidocaine test. Treatment is achieved by relieving the contact point by medical or surgical means. We report a 51-year-old female patient who suffered from left periorbital pain, and left posterior nasal drip for 30 years. The patient had middle concha bullosa which contained a fungal ball that caused periorbital headache. Anterior ethmoidectomy, middle meatalantrostomy, and middle concha bullosectomy were performed using nasal endoscopy, and subsequently the symptoms disappeared. We report on this case of middle turbinate headache syndrome and the successful results of endoscopic surgical treatment.

Korean J Otorhinolaryngol-Head Neck Surg 2014;57(9):623-5

Key Word Middle turbinate headache syndrome.

\section{서 론}

중비갑개 두통 증후군(middle turbinate headache syndrome) 은 $\mathrm{Wolff}^{1}$ 에 의해 처음 소개된 질환으로 중비갑개가 비대화 또는 함기화 되어 비중격이나 측면의 코 벽을 압박하여 눈 주 변부 두통을 주된 증상으로 하는 증후군이다. 중비갑개와 비중격은 삼차신경(trigeminal nerve)의 안신경(ophthalmic nerve)의 분지인 전 사골신경(anterior ethmoidal nerve)의 지 배를 받기 때문에 이 구조물의 압박은 상안와, 내안각 부위 (medial canthus)의 통증을 유발한다. 그 외 부비동염의 동반 이 없고, 간헐적이고 편측성인 안와부 주변부의 통증과 일 반적인 진통제에도 반응하지 않으면서 비점막이 수축되고 난 이후부터 통증이 완화되는 것을 특징으로 한다. 이 질환은 임 상병력, 비내시경 관찰, 컴퓨터단층촬영, 리도카인 테스트 (lidocaine test)를 통해 진단할 수 있다. 의심하지 않으면 진단
하기 어려운 본 질환의 특성상 정확한 유병률은 아직 보고되 어 있지 않으며 ${ }^{2}$ 아직까지 국내에서는 기포성 중비갑개에 의 한 만성 두통 증후군의 보고 사례는 없다.

이에 저자들은 30 년 동안 두통을 호소한 환자를 함기화된 중비갑개 내의 진균구(fungal ball)로 인한 중비갑개 두통 증 후군으로 진단하고, 내시경 부비동 수술로 효과적으로 치료한 사례가 있어 이를 보고하고자 한다.

\section{증 계}

51세 여자 환자가 고등학교 때부터 30년 이상 지속된 두통, 후비루 증상으로 내원하였다. 두통의 양상은 좌측 안와부 주 위 및 좌측 전두동 부위로, 심한 통증을 호소하였으며, 항생 제 및 진통제를 복용하여도 투약시에만 일시적인 통증 감소 를 보일 뿐 증상의 호전은 없었다. 내원 5개월 전부터 두통, 비 

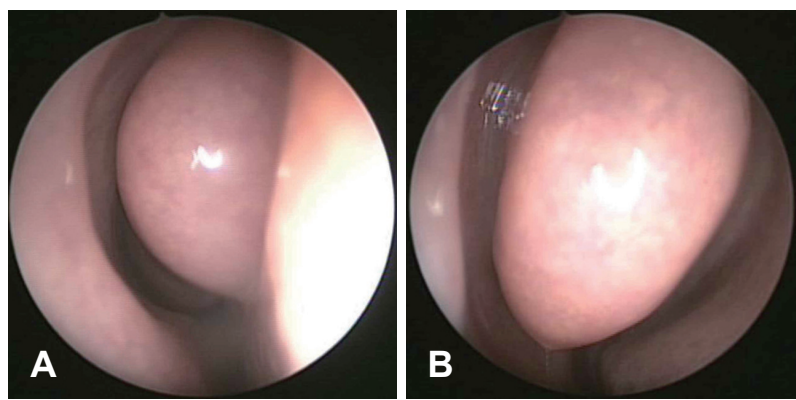

Fig. 1. Preoperative endoscopic views of both nasal cavity. Enlarged left middle turbinate was seen. Rt. nasal cavity (A). Lt. nasal cavity (B).

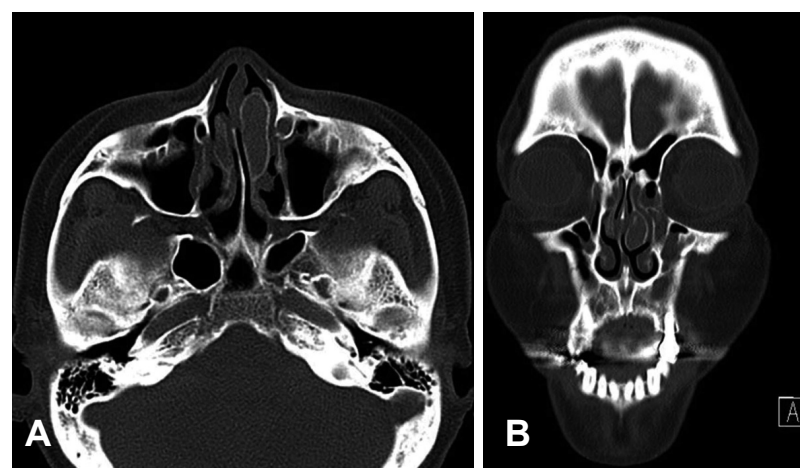

Fig. 2. Preoperative CT scans. Axial view (A). Coronal view (B). These CT scans show large concha bullosa in left middle turbinate, which compress nasal septum.

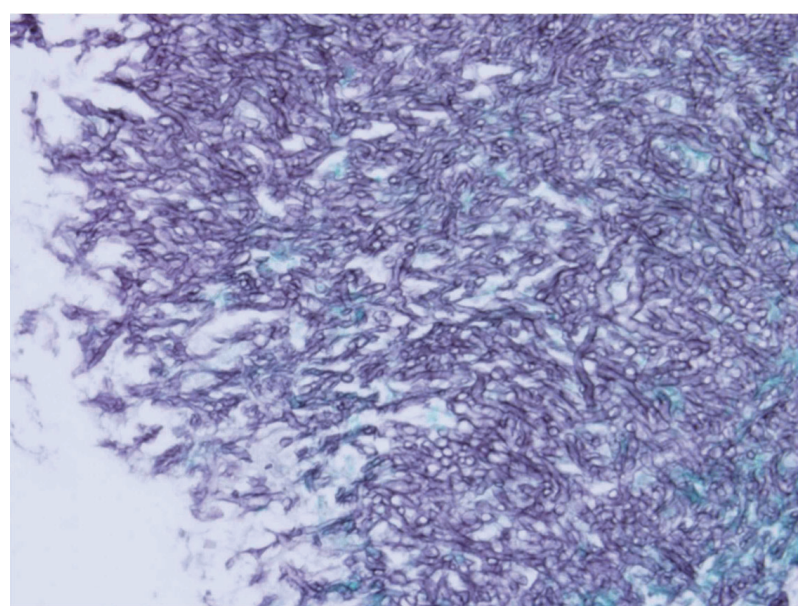

Fig. 3. Histopathologic finding. Numerous fungal hyphae is shown [Grocott's Methenamine Silver (GMS) stain, ×400].

폐색 증상이 더 심해지는 양상을 보여, 타병원에서 부비동 단 순촬영과 부비동 전산화단층촬영을 하였으며 기포성 중비갑 개 소견 외에 다른 염증소견은 관찰되지 않았다. 또한 리도카 인 테스트 상 증상의 호전 양상을 보이지 않아 약물 치료를 시 행하였으며 수술적 치료를 받진 않았다.

과거력 상 내원 10개월 전부터 당뇨로 진단받고 약물 복용 중이었으며 코 수술을 받은 적은 없었다. 비내시경 상 좌측 중 비갑개가 비대화 되어 비중격에 닿아 압력을 가하고 있었으

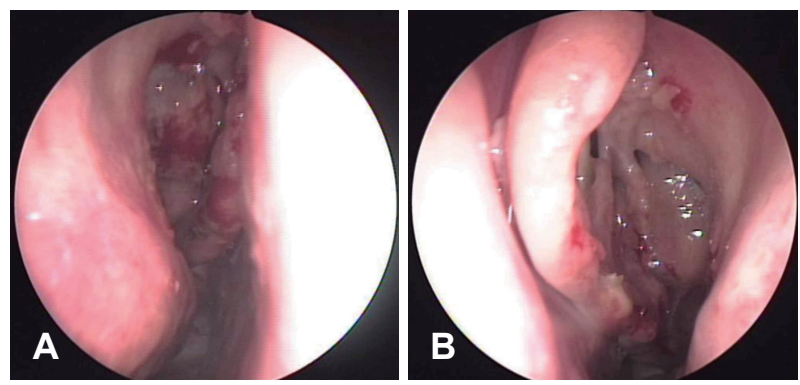

Fig. 4. Postoperative endoscopic views of both nasal cavity 1 month after surgery. Lateral side of left middle turbinate was resected. Rt. nasal cavity (A). Lt. nasal cavity (B).

며, 전산화단층촬영 상 좌측의 비대화된 기포성 갑개(concha bullosa)가 비중격과 접촉하는 양상이 관찰되었다. 우측에도 기포성 갑개 소견이 관찰되었으나 양측의 부비동 병변은 없었 다(Figs. 1 and 2). 전신마취 하에 양측의 전방 사골절제술(anterior ethmoidectomy) 및 양측의 중비도 개창술(middle meatal antrostomy), 양측 비대성 중비갑개 절제술(middle concha bullosectomy)을 시행하였다. 비대화된 좌측 중비갑개 의 외측 $1 / 2$ 을 절제한 후 안의 조직을 채취하였으며 조직 검 사 상 아스페르질루스(aspergilloma)로 진단되었다(Fig. 3). 수 술 직후 환자의 두통이 호전되었으며 수술 3일째 퇴원하였 다. 술 후 1 개월째 비내시경 상 비중격을 누르고 있던 기포성 중비갑개의 외측연이 제거된 것을 관찰할 수 있었다(Fig. 4). 환자는 퇴원 이후 6 개월까지 경과관찰 하고 있으며 두통의 재 발 및 가피 형성, 감염, 위축성 비염과 같은 합병증 소견은 관 찰되지 않았다.

\section{고 찰}

두통은 임상의들에게 까다로운 증상으로 다른 질환의 증상 으로 중첩되는 경우가 많아 감별진단이 어려워 치료 성적이 낮 다. 긴장성 두통, 편두통은 병인론이 밝혀져 있지만, 아직은 원인이 밝혀지지 않은 두통이 많이 있으며 적절한 진단을 위 해 많은 경험과 연구가 필요하다. ${ }^{3)}$ 비성 두통은 이러한 두통 중 하나로 전체 두통 중 $10 \%$ 이하를 차지하며, 중비갑개 두 통 증후군은 비성 두통의 한 종류로, Wolff ${ }^{1)}$ 가 처음으로 중비 갑개 두통 증후군의 원인을 보고하였다. 주로 편측성 간헐적 안와부의 두통으로 발현되며 간혹 비폐색과 함께 나타난다 는 특징이 있다. 비폐색과 비루 증상이 동반된 두통 환자는 부 비동 질환과 감별하기 위하여 신중한 병력청취와 신체검사가 필요하며 편두통, 군집성 두통, 긴장성 두통, 신경통, 측두하악 관절 장애에 의한 두통 같은 질환들과도 감별해야 한다. ${ }^{5)}$ 중 비갑개의 전방부는 삼차신경 안신경 분절의 분지인 전 사골신 경이 분포되어 있다. 이 부위에 자극을 받았을 경우 내안각과 
상안와 부위에 통증이 발생한다. 중비갑개 전방부에 인접한 비 중격 부위는 전 사골신경의 비중격 분지(septal branch)의 신 경지배를 받으며 자극 될시에 유사한 부위에 통증이 발생한 다. 통증이 일반적으로 일측성이며 간헐적인 것은 편측성 중 비갑개 비대가 더 흔하고 비주기에 따른 점막 부종의 변화가 있기 때문이다. 또한 중력의 변화에 따라 비점막 충혈이 변하 기 때문에 환자가 서 있는 경우 통증이 경감하기도 한다.)

Wolff ${ }^{1)}$ 가 삼차신경의 감각신경 분지(sensory branch)들이 분포한 비점막을 자극시킬 경우 통증이 발생한다고 최초로 보고한 이후, Becker ${ }^{\circ}$ 는 전 사골신경이 분포하는 중비갑개의 전방부와 인접 비중격에 자극을 가했을 경우, 내안각과 안와 부의 연관통이 발생할 수 있다고 보고하였다. Stammberger 와 Wolf ${ }^{7)}$ 는 비점막이 자극될 경우 substance P라는 신경단백 질(neuroprotein)이 분비되고 substance $\mathrm{P}$ 는 말초기관에 작용 하여 혈관이완(vasodilation), 과분비(hypersecretion)를 일으 키고, 대뇌에 작용할 경우 연관통을 일으킨다고 보고하였고, Morgenstein과 Krieger ${ }^{8)}$ 는 전형적인 중비갑개 두통 증후군 은 부비동염과 무관하며 비순환과 부종 여부에 따라서 안와부, 내측 안각 또는 관자광대영역(temporozygomatic region)의 통증과 증상들이 달라질 수 있다고 하였다. 다른 질환과의 감 별을 위하여 비대화된 중비갑개가 비중격 또는 측면의 비벽 과 직접 접촉하는지 비내시경으로 확인하는 것이 중요하며, 점 막이 비대화, 함기화 된 경우 전산화단층촬영을 하여 다른 질환과 감별해 주어야 한다. 그 외 진단법으로 중비갑개점막 접촉 부위에 국소 마취제를 도포하였을 경우 두통이 소실된 다면 중비갑개 두통 증후군을 확진할 수 있으며, 다른 두통과 는 달리 에르고타민(ergotamine) 또는 혈관수축제(vasoconstrictor)에 반응을 보이지 않으며, 교감 신경 흥분제(sympathomimetics)와 항히스타민(antihistamine)과 같이 점막부 종을 감소시키는 약, 또는 국소 스테로이드(steroid) 제제로 두 통이 경감되면 충분히 의심해 볼 수 있다.910) 수술적 방법에는 부분적 중비갑개 교정술(partial middle turbinoplasty) 또는 중 비갑개 절제술(middle turbinectomy)이 있으며 가능하다면 비 중격 교정술(septoplasty)을 같이 해주는 것이 좋다. ${ }^{8)}$ Morgenstein과 Krieger ${ }^{8}$ 는 19 명의 중비갑개 두통 증후군 환자 중 17 명을 수술적인 방법으로 성공적으로 치료하였으며 가피형성, 위축성 비염, 감염과 같은 합병증은 없었다고 보고했다. $\mathrm{Chow}^{10}$
는 비내시경적 수술 방법으로 접촉성 두통을 치료하여 $82 \%$ 의 성공률을 보고하였고, Parsons와 Batra ${ }^{11}$ 는 19 명의 성인과 15 명의 소아에서 $91 \%$ 의 성공률을 보고하였다.

중비갑개 두통 증후군은 임상적 증상, 비내시경 관찰, 컴퓨 터단층촬영 같은 여러 방법으로 진단하며 내과적 치료, 수술 적 치료 둘 다 성공적으로 치료 가능하지만 비강의 구조적인 이상이 원인인 경우 수술적 치료가 우선시 된다. 본 예의 경우 비대화된 중비갑개에 의해 30년간 지속된 환자의 증상이 중 비갑개 두통 증후군의 증상과 일치하며, 진균구에 의해 더욱 비대화 된 중비갑개가 수술 후 비중격 점막을 압박하고 있던 것이 사라져서 두통이 호전된 양상을 보였다. 이에 최종적으로 중비갑개 두통 증후군으로 진단하였다. 환자가 호소하던 후 비루 증상 역시 수술 후 호전되었는데 이는 기포성 중비갑개 안의 진균구로 인한 것이라고 생각된다. 이상으로 저자들은 진 균구(fungal ball)를 함유한 중비갑개 두통 증후군을 내시경 부비동 수술로 성공적으로 치료하였기에 본 증례를 보고하는 바이다.

\section{REFERENCES}

1) Wolff HG. The nasal, paranasal, and aural structures as sources of headache and other pain. In: Wolff HG, editor. Headache and other pain. New York: Oxford University Press;1948. p.532-60.

2) Anselmo-Lima WT, de Oliveira JA, Speciali JG, Bordini C, dos Santos $\mathrm{AC}$, Rocha KV, et al. Middle turbinate headache syndrome. Headache 1997;37(2):102-6.

3) Goldsmith AJ, Zahts GD, Stegnjajic A, Shikowitz M. Middle turbinate headache syndrome. Am J Rhinol 1993;7:17-30.

4) Zilkha KJ. Headaches and facial pain. In: Scott B, Walter G, editors. Scott-Brown's Otolaryngology. 5th ed. Buterworths;1987. p.341-7.

5) Chow JM. Evaluation of rhinologic headaches. In: Stankiewicz JA, editor. Advanced endoscopic sinus surgery. St. Louis: Mosby;1991. p.121-6.

6) Becker SP. Anatomy for endoscopic sinus surgery. Otolaryngol Clin North Am 1989;22(4):677-82.

7) Stammberger H, Wolf G. Headaches and sinus disease: the endoscopic approach. Ann Otol Rhinol Laryngol Suppl 1988;134:3-23.

8) Morgenstein KM, Krieger MK. Experiences in middle turbinectomy. Laryngoscope 1980;90(10 Pt 1):1596-603.

9) Clerico DM. Sinus headaches reconsidered: referred cephalgia of rhinologic origin masquerading as refractory primary headaches. Headache 1995;35(4):185-92.

10) Chow JM. Rhinologic Headaches. Otolalyngol Head Neck Surg 1994; 111(3 Pt 1):211-8.

11) Parsons DS, Batra PS. Functional endoscopic sinus surgical outcomes for contact point headaches. Laryngoscope 1998;108(5):696-702. 